\title{
The invertebrate community of the chalk stream hyporheic zone: spatio-temporal distribution patterns
}

\author{
Octavian Pacioglu ${ }^{1,2, *}$ and Anne Robertson ${ }^{1}$ \\ ${ }^{1}$ Centre for Research in Ecology, Roehampton University, Holybourne Avenue, SW15 4JD London, UK \\ 2 Department of Biology-Chemistry, Faculty of Chemistry, Biology, Geography, West University of Timisoara, \\ 300115 Timisoara, Romania
}

\begin{abstract}
This study examined the longitudinal distribution, vertical distribution and temporal dynamics of the invertebrate community inhabiting the chalk hyporheic zone of four catchments, which differed in their degree of eutrophication and sediment composition. We characterised the invertebrate community at two depths $(20$ and $35 \mathrm{~cm}$ ), in the heads and tails of riffles at low and high groundwater levels. Taxon density declined significantly with increasing depth. The abundance of invertebrates did not differ significantly between the heads and tails of riffles and also did not respond to changes in groundwater level. The results suggest that the chalk hyporheic zone is a shallow habitat that is relatively homogenous at the riffle scale with respect to the distribution of fauna and potentially resilient to seasonal groundwater level fluctuations.
\end{abstract}

Keywords: hyporheic zone / upwelling and downwelling / vertical distribution / groundwater dynamic

Résumé - La communauté invertébrée de la zone hyporhéique d'une rivière calcaire : modèles de distribution spatio-temporelle. Cette étude a examiné la répartition longitudinale, la distribution verticale et la dynamique temporelle de la communauté d'invertébrés habitant la zone hyporhéique calcaire de quatre bassins, qui diffèrent par leur degré d'eutrophisation et la composition des sédiments. Nous avons caractérisé la communauté d'invertébrés à deux profondeurs $(20$ et $35 \mathrm{~cm})$, dans les têtes et les queues de rapides à des niveaux d'eau souterrains bas et élevés. La densité des taxons a diminué de façon significative avec l'augmentation de la profondeur. L'abondance d'invertébrés ne différait pas significativement entre les têtes et les queues des radiers et ne répondait pas non plus aux changements du niveau des eaux souterraines. Les résultats suggèrent que la zone hyporhéique calcaire est un habitat peu profond qui est relativement homogène à l'échelle du radier en ce qui concerne la distribution de la faune et potentiellement résilient aux fluctuations saisonnières du niveau d'eau souterraine.

Mots clés : zone hyporhéique / upwelling et downwelling / distribution verticale / dynamique des eaux souterraines

\section{Introduction}

It is widely recognised that the hyporheic zone (HZ, sensu Orghidan, 1955) plays a crucial role in the biogeochemical cycling of nutrients, dissolved oxygen and pollutants and provides refuge for fauna (hyporheos, sensu Boulton, 2000) during environmental disturbances (e.g. droughts, floods and colmation) (Boulton et al., 1998; Wood et al., 2010).

The role of $\mathrm{HZ}$ as an ecotone was acknowledged recently (Williams et al., 2010), but there are still unknown aspects of this habitat, particularly the importance of local conditions, type of geology, magnitude of water exchange between surface and groundwater and human impact (Boulton et al., 2010).

\footnotetext{
*Corresponding author: octavian.pacioglu@e-uvt.ro
}

Previous studies have examined the ecology, spatial distribution and temporal dynamics of the hyporheos in alluvial deposits lying along big rivers (Danielopol, 1976; Dole-Olivier et al., 1994) or meandering pristine catchments (e.g. hyporheic corridor concept, Stanford and Ward, 1993). Other studies have focused on smaller streams and their adjacent HZs, in sediments varying from sandy deposits (Goose Creek, Palmer, 1990) to cobbled limestone thalwegs (Stubbington et al., 2009), but there are still many sediment types where the HZ has not been properly characterised (Pacioglu, 2010).

One such sediment type is the chalk, an extensive habitat in the UK and in northern France (Finch et al., 2004). Epigean assemblages in chalk streams are well known (Harrison and Harris, 2002; Riley et al., 2009) but research designed to determine the main environmental parameters driving the spatial distribution and temporal dynamics of the hyporheos 
has been limited (Davy-Bowker et al., 2006; Tod and SchmidAraya, 2009). The possibility of using the chalk hyporheos as a biological indicator for eutrophication (Pacioglu et al., 2016) and colmation (Pacioglu et al., 2012; Jones et al., 2015) has been previously suggested, but a deeper understanding of the ecological requirements of this community is essential before it can be used in water and habitat quality assessments.

Chalk rivers are groundwater fed ecosystems, with small fluctuations in temperature and suspended sediments (Sear et al., 1999). The relationship between groundwater level and river flow in chalk streams follows a clear seasonal pattern (Berrie, 1992). Rising groundwater levels in winter produce an extension of river flow, with rivers responding rapidly to precipitation, whereas the summer is characterised by a constant low baseflow (Grapes et al., 2005). However, the importance of groundwater fluctuation as a driver for the temporal and spatial distribution of the chalk hyporheos is unknown, despite recent studies investigate the influence of seasonal droughts on the spatial distribution of chalk hyporheos in headwater streams (Wood et al., 2010; Stubbington et al., 2015).

The HZ is typically a heterogeneous habitat at the reach scale leading to significantly different invertebrate communities in the heads (usually downwelling zones) and tails (usually upwelling zones) of riffles. Downwelling zones are often associated with a higher frequency of epigean invertebrates, whereas there are increased proportions of stygobites in the upwelling zones (Williams, 1989; Dole-Olivier et al., 1994, 1997; Boulton et al., 2010). The density of invertebrates usually decreases with increasing depth (Danielopol, 1976; Dole-Olivier et al., 1994). Although the existence of the chalk hyporheos was recognised decades ago (Hynes, 1983), to our knowledge, only one study, in a single stream in southern UK, has investigated the vertical distribution of the chalk hyporheos (Davy-Bowker et al., 2006).

In the present study, we investigated the longitudinal and vertical distribution of the chalk hyporheos at the riffle and the regional scale, its dynamics over two seasons and the influence of water physico-chemistry and sediment characteristics in four rivers differing in the level of eutrophication and fine sediment load (Pacioglu et al., 2016). Three hypotheses were addressed:

$-\mathrm{H}_{1}$ : There is a heterogeneous distribution of the hyporheos at the reach scale (sensu Boulton et al., 1998); the community present in the heads and tails of riffles will differ.

$-\mathrm{H}_{2}$ : The invertebrate abundance declines with depth.

$-\mathrm{H}_{3}$ : Hyporheos abundance varies with groundwater levels.

\section{Materials and methods}

\subsection{Sampling strategy}

In order to test these hypotheses, four catchments were selected. The first two catchments (Rivers Piddle and Frome), situated in Dorset, south-west UK, are moderately eutrophic (mean surface water nitrate concentration/basin $23.68 \pm 1.7 \mathrm{mg}$ $\mathrm{NO}_{3}{ }^{-} \mathrm{L}^{-1}$ ). Land use is mainly characterised by agricultural fields and dairy farms (for more details of sampling sites and type of land use, see Pacioglu et al., 2016). The remaining two rivers, the Lee and Rib, are situated to the north of
London, United Kingdom and are bordered by a typical urban landscape (see Pacioglu et al., 2016). These urban rivers are highly polluted, mainly with nitrates (mean $54.16 \pm 2.08 \mathrm{mg}$ $\mathrm{NO}_{3}{ }^{-} \mathrm{L}^{-1}$ ), phosphates and ammonium (Flynn et al., 2002; Snook and Whitehead, 2004), whereas the surface water concentration of nitrates in these urban rivers is greater than the European maximal standards imposed by Water Framework Directive of $50 \mathrm{mg} \mathrm{L}^{-1}$ (Flynn et al., 2002), nitrate concentration diminishes with depth, so that in the $\mathrm{HZ}$ nitrate concentrations in all four rivers are similar (Tab. 1, Pacioglu et al., 2016).

In each catchment, four sampling sites were chosen in the headwaters, and for each site, two riffles were selected (with the exception of the River Lee where only 7 suitable riffles could be found), giving a total of 31 riffles. For each riffle, four replicates were taken from both the heads and tails of the riffles. The selected riffles were similar in size (on an average $0.5 \mathrm{~m}$ deep, 3-4 $\mathrm{m}$ wide and 5-7 $\mathrm{m}$ length). The survey was conducted twice, once at low water level (summer 2008) and once at high water level (winter 2008/2009). Samples were taken using piezometers, inserted into the head/tails of the riffles to the desired depth (either $20 \mathrm{~cm}$ or $35 \mathrm{~cm}$ ), and a BouRouch pump (Bou and Rouch, 1967) was used to extract $5 \mathrm{~L}$ of interstitial water/sample. For further details on the sampling strategy, the physico-chemical parameters measured, sediment characteristics and fauna, please refer Pacioglu et al. (2016). In summer of 2008 (July/August), the hyporheos was sampled from $35 \mathrm{~cm}$ depth, and in winter 2008/2009 (December/ January), samples were additionally collected from $20 \mathrm{~cm}$, because preliminary results indicated low abundance of hyporheos at $35 \mathrm{~cm}$ depth (Pacioglu, 2011). Throughout the sampling, temperature was recorded at every sampling site and depth at both the heads and tails of riffles, and the relative difference (RT) between the HZ and surface water temperature was calculated (Davy-Bowker et al., 2006). Sediment samples were collected from each riffle by excavating the sediment to a depth of $15 \mathrm{~cm}$. The percentage of fines (with a diameter smaller than $2 \mathrm{~mm}$ ) and $\mathrm{D}_{50}$ (the median interstitial space represented by the median of the distribution of sediment per size classes) was estimated according to Olsen and Townsend (2003) (more details in Pacioglu et al., 2016).

\subsection{Statistical analysis}

Prior to statistical analyses, all samples were $\log (x+1)$ transformed, checked for normality (Kolmogorov-Smirnoff test) and compared to assess for differences between rivers and depths by three-way nested ANOVA models, with riffles considered as a random variable (winter only, Tab. 1). Twoway factorial ANOVA tests were used to test for differences of physico-chemical parameters between the heads and tails of the riffles, rivers and their interactions (Tab. 2). Further, two-way ANOVA models were used to test for the relative differences in temperature (RT, see above) between heads and tails of riffles and rivers, separately for each season. The sediment physical parameters were compared using a KruskalWallis (K-W) test between rivers, together with post-hoc Mann-Whitney (M-W) tests with Bonferroni corrections.

Apart from total invertebrates and Chironomidae abundance, no taxa were normally distributed, nor could an effective normalising transformation be found. Therefore, 
O. Pacioglu and A. Robertson: Knowl. Manag. Aquat. Ecosyst. 2017, 418, 10

Table 1. Three-way nested ANOVA model for physico-chemical parameters between rivers, depth, with riffles considered as random variable (winter only). ${ }^{*} P<0.01,{ }^{*} P<0.001$ significance levels. $\mathrm{Df}=$ degrees of freedom and $F=$ the values of $F$-test.

\begin{tabular}{llcccc}
\hline Variables & Df & Temperature & pH & Conductivity & Dissolved oxygen \\
\hline River & 3 & $161^{* *}$ & $54.6^{* *}$ & $185.2^{* *}$ & $26.6^{* *}$ \\
Depth & 1 & 0.002 & $51.7^{* *}$ & 1.34 & $9.54^{*}$ \\
River $\times$ riffle & 3 & 2.651 & $4.18^{* *}$ & 0.6 & 0.7 \\
River $\times$ depth & 8 & 1.46 & 0.16 & 0.59 & 1.26
\end{tabular}

\begin{tabular}{|c|c|c|c|c|c|}
\hline & & $\mathrm{NO}_{3}{ }^{-}$ & $\mathrm{SO}_{4}{ }^{2-}$ & $\mathrm{Cl}^{-}$ & $\mathrm{NH}_{4}^{+}$ \\
\hline River & 3 & $81.7 * *$ & $95.25 * *$ & $77.64 * *$ & $7.54 * *$ \\
\hline Depth & 1 & $6.45^{*}$ & 1.11 & 2.77 & 2.1 \\
\hline River $\times$ riffle & 3 & 0.32 & 1.9 & 1.38 & 1.07 \\
\hline \multirow[t]{2}{*}{ River $\times$ depth } & 8 & 0.06 & 0.5 & 0.67 & 0.03 \\
\hline & & $\mathrm{Na}^{+}$ & $\mathrm{K}^{+}$ & $\mathrm{Mg}^{2+}$ & $\mathrm{Ca}^{2+}$ \\
\hline River & 3 & $70.15^{* *}$ & $51.4^{* *}$ & $9.75 * *$ & $66.9 * *$ \\
\hline Depth & 1 & 1.64 & 1.6 & 1.76 & 0.06 \\
\hline River $\times$ riffle & 3 & 1.41 & 1.9 & 2.34 & 0.25 \\
\hline River $\times$ depth & 8 & 0.94 & 0.57 & 1.77 & 1.84 \\
\hline
\end{tabular}

Table 2. $F$ values for two-way factorial ANOVA model for physico-chemical variables between rivers and heads/tails of riffles, with 488 degrees of freedom for model error. $* P<0.01, * * P<0.001$ significance levels. $\mathrm{Df}=$ degrees of freedom.

\begin{tabular}{|c|c|c|c|c|c|c|}
\hline Treatment & Df & $\mathrm{O}_{2}$ & Df & $\mathrm{NO}_{3}{ }^{-}$ & Df & $\mathrm{pH}$ \\
\hline River & 3 & $11.1^{* *}$ & 3 & $56.7 * *$ & 3 & $23.03 * *$ \\
\hline Head/tail & 1 & $4.9^{*}$ & 1 & 3.7 & 1 & 1.9 \\
\hline \multirow[t]{2}{*}{ River $\times$ head/tail } & 3 & 2.4 & 3 & 2.4 & 3 & 2.9 \\
\hline & & $\mathrm{NH}_{4}^{+}$ & & Temperature & & $\mathrm{SO}_{4}{ }^{2-}$ \\
\hline River & 3 & 0.7 & 3 & $19.35^{* *}$ & 3 & $105.6^{* *}$ \\
\hline Head/tail & 1 & 0.2 & 1 & 0.15 & 1 & 1.13 \\
\hline River $\times$ head/tail & 3 & 4.1 & 3 & 0.07 & 3 & 2.02 \\
\hline
\end{tabular}

\begin{tabular}{|c|c|c|c|c|c|c|}
\hline & & Conductivity & & $\mathrm{Cl}^{-}$ & & $\mathrm{Na}^{+}$ \\
\hline River & 3 & $317.3 * *$ & 3 & $54.6 * *$ & 3 & $75.08 * *$ \\
\hline Head/tail & 1 & 0.7 & 1 & 0.06 & 1 & 0.07 \\
\hline \multirow[t]{2}{*}{ River $\times$ head/tail } & 3 & 0.4 & 3 & 3.25 & 3 & 0.23 \\
\hline & & $\mathrm{PO}_{4}{ }^{3-}$ & & $\mathrm{K}^{+}$ & & $\mathrm{Mg}^{2+}$ \\
\hline River & 3 & $3.4^{* *}$ & 3 & $58.94 * *$ & 3 & 20.3 \\
\hline Head/tail & 1 & 0.47 & 1 & 0.06 & 1 & 2.3 \\
\hline River $\times$ head/tail & 3 & 2.6 & 3 & 0.2 & 3 & 2.1 \\
\hline
\end{tabular}

comparisons between seasons were undertaken using $\mathrm{M}-\mathrm{W}$ tests with Bonferroni corrections for each catchment. The total abundance was estimated as number of individuals $/ 5 \mathrm{~L}$ of interstitial water. The variation in total abundance of invertebrates between rivers and sampling depths during winter was assessed with a two-way ANOVA model. One-way randomisation test, ANOSIM (analysis of similarities), was used to identify differences in the structure of the hyporheos between the heads and tails of the riffles during summer. A two-way ANOSIM test was applied to check for differences between the heads and tails of riffles, and sampling depths, during winter (software PAST 2.01) (Tab. 3). 
Table 3. $R$ values from one-way (summer) and two-way (winter) ANOSIM tests in Dorset (Rivers Frome and Piddle) and London (Rivers Rib and Lee). The one-way ANOSIM tests for differences in community composition between heads and tails of riffles at one depth $(35 \mathrm{~cm})$ during summer. The two-way ANOSIM test for differences with depth $(20$ and $35 \mathrm{~cm}$ ), in addition to the distribution of fauna between heads and tails of riffles. Significant values $(P<0.05)$ are in bold.

\begin{tabular}{lllll}
\hline Position & $\begin{array}{l}\text { Dorset } \\
\text { Summer }\end{array}$ & $\begin{array}{l}\text { Dorset } \\
\text { Winter }\end{array}$ & $\begin{array}{l}\text { London } \\
\text { Summer }\end{array}$ & $\begin{array}{l}\text { London } \\
\text { Winter }\end{array}$ \\
\hline Head vs. tail & 0.045 & $\mathbf{0 . 0 1}$ & 0.001 & $\mathbf{0 . 0 6}$ \\
Depth & - & 0.02 & - & $\mathbf{0 . 0 4}$ \\
\hline
\end{tabular}

\section{Results}

\subsection{Abiotic factors and sediment characteristics}

Most physico-chemical parameters differed significantly among rivers, but did not differ significantly with depth with the exception of $\mathrm{pH}$, dissolved oxygen and nitrates (Tab. 1). Physico-chemical parameters of the interstitial water did not differ significantly between the heads and tails of the riffles, apart from dissolved oxygen in the River Frome $(P=0.03$, three-way ANOVA; Tab. 2). Despite strong similarities in the physico-chemistry of the surface stream and the HZ, the mean RT was generally smaller in the heads of riffles compared to the tails during summer (Fig. $1, F_{1,247}=58.58$, $P<0.001$, two-way ANOVA). The mean RT during winter did not significantly differ between riffle heads and tails (Fig. 1, $F_{1,247}=0.057, P>0.05$, two-way ANOVA). The four rivers differed significantly in the percentage of fine sediments they possessed $\left(P<0.01, \chi^{2}=155.23,3 \mathrm{df}, \mathrm{K}-\mathrm{W}\right.$ test $)$, and the lowest values were found in the river Rib (Fig. 2). The median diameter of interstitial space $\left(\mathrm{D}_{50}\right)$ was inversely related to the percentage of fine sediments and differed significantly between the rivers $\left(P<0.01, \chi^{2}=191.001,3 \mathrm{df}, \mathrm{K}-\mathrm{W}\right.$ test $)$.

\subsection{Hyporheos spatial distribution and diversity over time}

The total abundance of invertebrates in the chalk HZ differed significantly between sampling depths during winter $\left(F_{1,248}=9.19, P=0.003\right.$, two-way ANOVA $)$, but not between rivers $\left(F_{3,248}=1.14, P>0.05\right.$, two-way ANOVA) (Fig. 3). ANOSIM $R$ values comparing species composition across heads and tails of riffles in winter (2 depths) and summer in both hydrographical basins (Tab. 3) were either not significant or marginally significant suggesting little difference in $\mathrm{HZ}$ community composition between riffle heads and tails and depth. For most taxa, abundance did not differ significantly between low and high groundwater level at $35 \mathrm{~cm}$ depth (Appendices 1A and 1B). There were, however, a few exceptions: Chironomidae density was higher during winter in the River Lee $(P<0.0025, \mathrm{M}-\mathrm{W}$ test with Poisson correction $)$ and higher during winter for the Glossosomatids in the River Frome $(P<0.0025, \mathrm{M}-\mathrm{W}$ test, Poisson correction $)$ (Appendices 1 and 2). There was no significant fluctuation in stygofauna or stygophilic microcrustaceans abundance across seasons for all rivers $(P>0.05, \mathrm{M}-\mathrm{W}$ test $)$ (Appendices 1 and 2$)$.

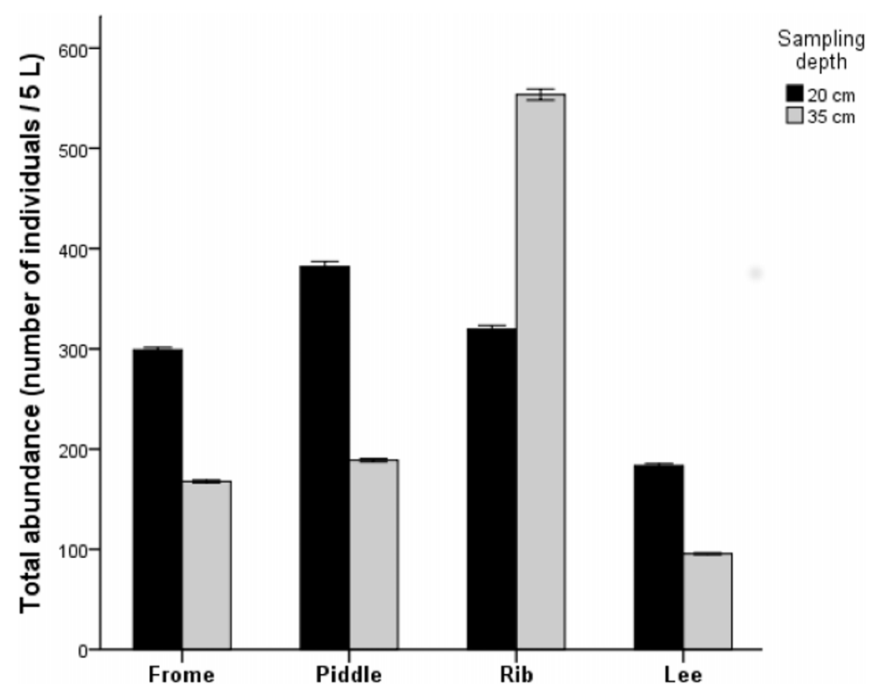

Fig. 1. Variation of temperature difference between hyporheic and river habitats as error bars, between the head and tail of riffles for all four rivers during summer and winter.

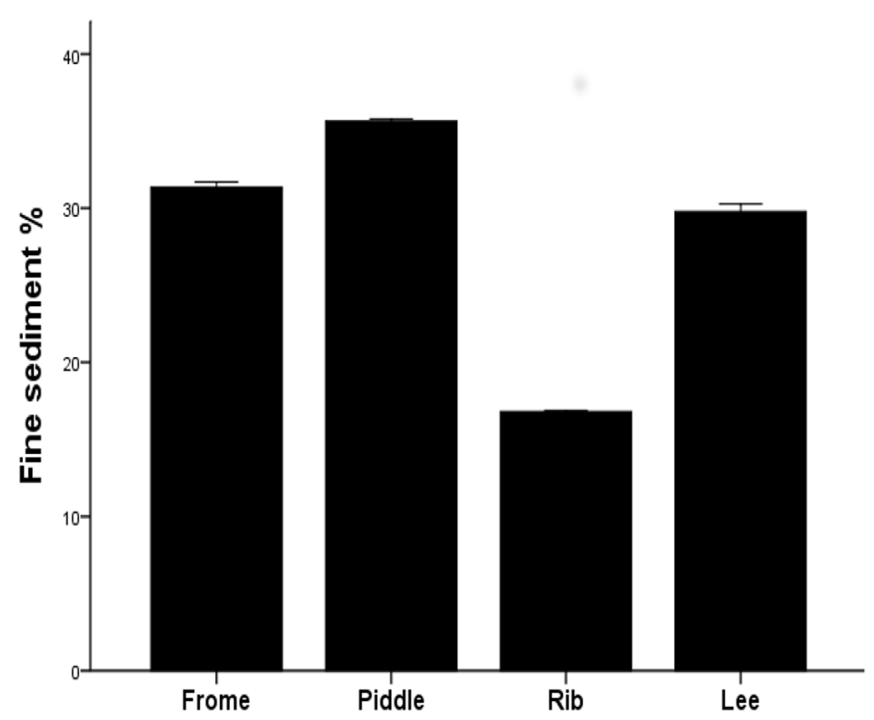

Fig. 2. Percentage of fine sediment (mean $\pm 1 \mathrm{SE})$ in the $\mathrm{HZ}$ of each river.

\section{Discussion}

\section{1 $\mathrm{H}_{1}$ : Distribution of fauna in the heads and tails of riffles}

In our study, the HZ chemistry, with the exception of dissolved oxygen in the river Frome, did not differ significantly between the heads and the tails of riffles, suggesting that discrete downwelling zones are rare in these chalk rivers. Nevertheless, the mean RT in riffle heads and tails had a different pattern during summer, which is consistent with the thermal characteristics observed in down and upwelling areas of the $\mathrm{HZ}$ in other types of streams (Evans and Petts, 1997; Franken et al., 2001). Other 

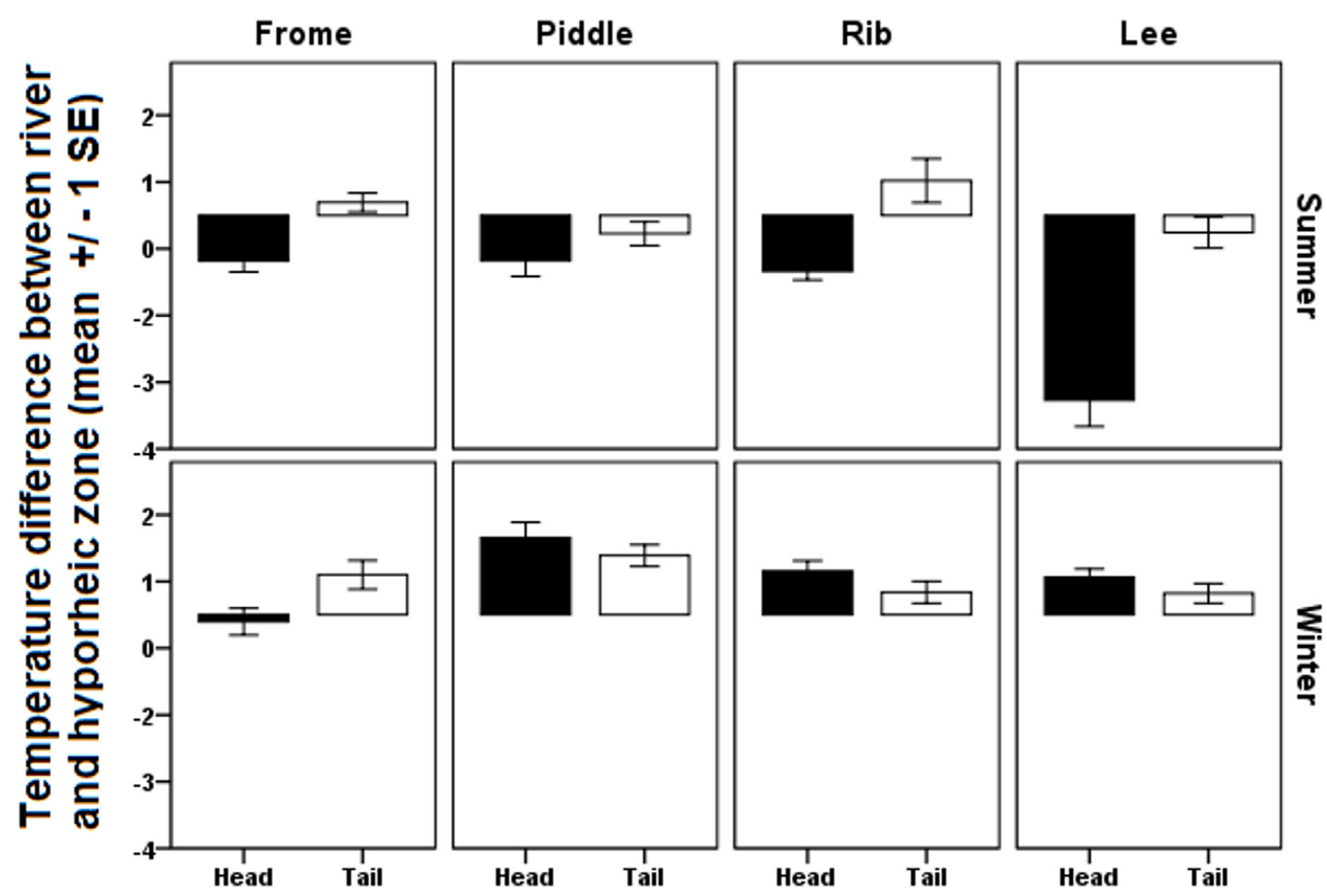

Fig. 3. Total abundance (mean $\pm 1 \mathrm{SE}$ ) of the hyporheos in the four catchments, for both $20 \mathrm{~cm}$ and $35 \mathrm{~cm}$ depth during winter.

studies have used temperature to identify upwelling and downwelling areas in chalk streams with variable success (Davy-Bowker et al., 2006; Pretty et al., 2006). Possibly in groundwater fed streams, surface water penetration into the river bed is restricted by large positive pressure gradients exerted by strongly upwelling subsurface waters (Hill and Limbourner, 1998).

There is an extensive literature suggesting that hyporheic assemblages in the heads (downwelling) and tails (upwelling) of riffles differ. Downwelling assemblages comprise mainly species of epigean origin with higher oxygen requirements, whereas upwelling assemblages usually include a higher proportion of hypogean species (Williams, 1989; Dole-Olivier et al., 1994, 1997; Boulton et al., 1998). However, we did not find any significant differences in the hyporheos assemblages of riffle heads and riffle tails in our four chalk catchments, and this is consistent with previous findings from the River Frome (Davy-Bowker et al., 2006). Previous studies have suggested that groundwater fed chalk rivers, in contrast to rivers flowing through other geologies (Dole-Olivier et al., 1994), lack strong downwelling zones and are dominated by a general upwelling tendency, resulting in a homogeneous interstitial habitat (including physico-chemical parameters) (Hill and Limbourner 1998; Pretty et al., 2006; Abesser et al., 2008). The archetypal structure of riffles (with downwelling head and upwelling tail flow paths) is difficult to find in chalk streams (Davy-Bowker et al., 2006), mainly because of human interventions since historic times (e.g. river strengthening, construction of weirs, water deflection channels) (Harrison and Harris, 2002). Moreover, other factors such as the heteroge- neity of subsurface flow paths, differences in substrate composition (e.g. chalk putty, layers of impermeable clay not apparent from the surface) and the presence of potential natural obstacles such as mid-bars may prevent the clearly defined zones of downwelling often associated with the head of riffles (Harvey and Bencala, 1993; Jones et al., 1995; Pretty et al., 2006).

\section{2 $\mathrm{H}_{2}$ : Vertical distribution of chalk hyporheos}

As predicted, we found lower densities of taxa at greater depths in the HZ, a pattern shown by the majority of hyporheic studies (Dole-Olivier et al., 1994; Marchant, 1995), including the chalk river Frome (Davy-Bowker et al., 2006). Other studies have found that in big rivers such as the Rhone, Upper Danube or Oklahoma, the fauna characteristic of deep interstitial habitats (between $0.5 \mathrm{~m}$ and $1 \mathrm{~m}$ depth) differs from that in the superficial layers (Danielopol, 1976; Dole-Olivier et al., 1994; Boulton et al., 1998; Hunt and Stanley, 2003). However, this was not the case in our study perhaps because the HZ in chalk streams is typically shallow (perhaps up to $40 \mathrm{~cm}$, as suggested previously by Davy-Bowker et al., 2006; Pretty et al., 2006). The shallowness of chalk HZ may result from the peculiar geomorphology and surface/subsurface water exchange of chalk streams. Chalk streams possess a small number of tributaries and low topographic slopes in addition to the absence of typical riffle-pool-riffle sequences (Sear et al., 1999). Because of the upwelling tendency of groundwater, the chalk HZ is effectively squeezed between two extensive dynamic habitats: the river and the unconfined phreatic aquifer (Pretty et al., 2006), 
reducing the potential for a vertical extension of this habitat. In this respect, the chalk HZ has very different and apparently unique characteristics compared to other types of geology.

\subsection{1 $\mathrm{H}_{3}$ : Influence of groundwater level variation on the distribution of chalk hyporheos}

The temporal dynamics of the chalk hyporheos in the present study showed no clear patterns. There were no significant differences in the abundance of dominant groups between sampling seasons. Glossosomatids were significantly more abundant during winter as compared to summer for the river Frome, but this was not the case in the neighbouring River Piddle. These caddisflies are known to be univoltine taxa, with the first instars occurring in August; their growth rate is initially slow and then increases the next spring (Iversen, 1976). Moreover, the stygofauna and stygophilic microcrustaceans abundance showed no significant fluctuation among seasons, suggesting that the increased groundwater level during winter does not affect the vertical migration of these subterranean groups. Our findings contrast with chalk stream benthic communities which typically exhibit strong seasonal patterns (Harrison and Harris, 2002) and with stygofauna from shallow subsurface habitats, which have been found to be significantly influenced by increasing water levels during winter (Gledhill and Ladle, 1969; Gledhill, 1977). Although recent studies underlined the importance of base flow reduction in structuring the composition of chalk hyporheos during summer (Wood et al., 2010; Stubbington et al., 2015), the importance of upwelling fluctuations of groundwater on chalk hyporheos distribution has not yet been tested. The vertical downward migration of benthic insects and amphipods into the chalk HZ may be influenced by a decrease in dissolved oxygen availability and an increase of temperature, associated with summer low flows (Wood et al., 2010). Therefore, we conclude that the apparent lack of groundwater influence may result from stochastic vertical migration events of invertebrates between two major thoroughfares bordering the chalk HZ: the rivers and shallow phreatic waters.

\section{Conclusion}

Although the chalk HZ has a limited vertical development (approx. $40 \mathrm{~cm}$ deep) in comparison with the HZs of rivers on other geologies, it is likely to be of major importance for the functionality of the whole chalk stream ecosystem. The hyporheos largely comprises epigean taxa, reflecting the close proximity to benthic habitats and its ecotonal nature. The taxonomic composition of the hyporheos was very similar in the heads and tails of riffles and did not differ between seasons, perhaps because groundwater inputs dominate in chalk streams and strong downwelling zones are uncommon. Thus, the hyporheos in chalk streams appears to be a stable and quite homogeneous community and the down/upward migrations of invertebrates through the $\mathrm{HZ}$ over a year is the result of stochastic migration events between rivers and shallow subsurface waters.

Acknowledgements. The authors are grateful to Dr. Mark Dunscombe, for the long hours spent in the field during the sampling campaigns. The access to Environment Agency chemical database would have not been possible without the kind support of Dr. Bill Brierley. We are thankful to Don Fisher and Josie Hilleyard for their help in running numerous chemical analysis of HPLC and to Dr. John Murphy (Queen Mary University of London) for useful comments on this manuscript. The enthusiastic taxonomic help of Terry Gledhill (water mites), Dr. Rony Huys (identification of Parastenocaris fontinalis and advice in the taxonomy of harpacticoids) and of Dr. David Horne (confirmation for some of the ostracods identification) is gratefully acknowledged. OP was supported by a research $\mathrm{PhD}$ fellowship provided by Roehampton University, London, United Kingdom.

\section{References}

Abesser C, Shand P, Gooddy D, Peach D. The role of alluvial valley deposits in groundwater surface water exchange in a Chalk river. In: Abesser C, Wagener T, Nuetzmann G., eds. Groundwatersurface water interaction: process understanding, conceptualization and modelling. Perugia: IAHS Press, 2008, pp. 11-20.

Berrie AD. 1992. The chalk stream environment. Hydrobiologia 248: 3-9.

Bou C, Rouch R. 1967. Un nouveau champ de recherche sur la faune aquatique souterraine. Comp Rend Acad Sci 265: 369-370.

Boulton A, Findlay S, Marmonier P, Stanley E, Vallet M. 1998. The functional significance of the hyporheic zone in streams and rivers. Ann Rev Ecol Syst 29: 59-81.

Boulton AJ. 2000. The subsurface macrofauna. In Jones JB, Mulholland PJ, eds. Streams and ground waters. San Diego, California: Academic Press, pp. 120-137.

Boulton AJ, Datry T, Kasahara T, Mutz M, Standford JA. 2010. Ecology and management of the hyporheic zone: streamgroundwater interactions of running waters and their floodplains. J North Am Benthol Soc 29: 26-40.

Danielopol DL. 1976. The distribution of the fauna in the interstitial habitats of riverine sediments of the Danube and the Piestig (Austria). Int J Speleol 8: 23-51.

Davy-Bowker J-D, Sweeting W, Wright N, Clark RT, Arnott S. 2006. The distribution of benthic and hyporheic macroinvertebrates from the heads and tails of riffles. Hydrobiologia 563: 109-123.

Dole-Olivier MJ, Marmonier P, Creuzé des Châtelliers M, Martin D. 1994. Interstitial fauna associated with the alluvial deposits of the Rhone River (France). In: Danielopol D, Gibert J, Standford J, eds. Groundwater ecology. New York: Academic Press, pp. 140-176.

Dole-Olivier MJ, Marmonier P, Beffy JL. 1997. Response of invertebrates to lotic disturbances: is the hyporheic zone a patchy refugium? Freshwater Biol 37: 257-276.

Evans EC, Petts GE. 1997. Hyporheic temperature patterns within riffles. Hydrolog Sci J 42: 199-213.

Finch JW, Bradford RB, Hudson JA. 2004. The spatial distribution of groundwater flooding in a chalk catchment in southern England. Hydrol Process 18: 959-971.

Flynn NJ, Paddison T, Whitehead PG. 2002. INCA modelling of the Lee system: strategies or the reduction of nitrogen loads. Hydrol Earth Syst Sci 6: 467-483.

Franken RJ, Storey RG, Williams DD. 2001. Biological, chemical and physical characteristics of down-welling and up-welling zones in the hy-porheic zone of a north-temperate stream. Hydrobiologia 444: 183-195.

Gledhill T. 1977. Numerical fluctuations of four species of subterranean amphipods during a five year period. Crustaceana Suppl 4: 144-152. 
Gledhill T, Ladle M. 1969. Observations on the life history of the subterranean amphipod Niphargus aquilex aquilex Schiodte. Crustaceana 16: 51-56.

Grapes TR, Bradley C, Petts GE. 2005. Dynamics of river-aquifer interactions along a chalk stream: the River Lambourn, UK. Hydrol Process 19: 2035-2053.

Harrison SS, Harris IT. 2002. The effects of bank side management on chalk stream invertebrate communities. Freshwater Biol 47: 2233-2245.

Harvey JW, Bencala KE. 1993. The effect of streambed topography on surface-subsurface water exchange in mountain catchments. Water Resour Res 29: 89-98.

Hill AR, Limbourner DJ. 1998. Hyporheic zone chemistry and stream-subsurface exchange in two groundwater-fed streams. Can J Fish Aquat Sci 55: 495-506.

Hunt GW, Stanley EH. 2003. Environmental factors influencing the composition and distribution of the hyporheic fauna in Oklahoma streams: variation across ecoregions. Fund Appl Limnol 158: 1-23.

Hynes HBN. 1983. Groundwater and stream ecology. Hydrobiologia 100: 93-99.

Iversen TM. 1976. Life cycle and growth of Trichoptera in a Danish spring. Fund Appl Limnol 78: 482-493.

Jones JB, Fisher SG, Grimm NB. 1995. Vertical hydrologic exchange and ecosystem metabolism in a Sonoran Desert stream. Ecology 76: 942-952.

Jones JI, Growns I, Arnold A, McCall S, Bowes M. 2015. The effects of increased flow and fine sediment on hyporheic invertebrates and nutrients in stream mesocosms. Freshwater Biol 60: 813-826.

Marchant R. 1995. Seasonal variation in the vertical distribution of hyporheic invertebrates in an Australian upland river. Fund Appl Limnol 134: 441-457.

Olsen DA, Townsend CR. 2003. Hyporheic community composition in a gravel-bed stream: influence of vertical hydrological exchange, sediment structure and physicochemistry. Freshwater Biol 48: $1363-1378$.

Orghidan T. 1955. Un nou domeniu de viata acvatica subterana "Biotopul hiporeic". Bulet Sti Biol Acad RPR 7: 657-676.

Pacioglu O. 2010. Ecology of the hyporheic zone: a review. Cave Karst Sci 3: 69-76.

Pacioglu O. 2011. The effect of diffuse nitrate pollution and land use on hyporheic habitats in lowland English chalk rivers. $\mathrm{PhD}$ thesis. University of Roehampton, UK.
Pacioglu O, Shaw P, Robertson A. 2012. Patch scale response of hyporheic invertebrates to fine sediment removal in two chalk rivers. Fundam Appl Limnol 4: 283-288.

Pacioglu O, Moldovan OT, Shaw P, Robertson A. 2016. Response of invertebrates from the hyporheic zone of chalk rivers to eutrophication and land use. Environ Sci Pollut Res 23: 4741.

Palmer MA. 1990. Temporal and spatial dynamics of meiofauna within the hyporheic zone of Goose Creek, Virginia. J North Am Benthol Soc 9: 17-25.

Pretty JL, Hilldrew AG, Trimmer M. 2006. Nutrient dynamics in relation to surface-groundwater hydrological exchange in a groundwater fed chalk stream. J Hydrol 330: 84-100.

Riley WD, Pawson MG, Quayle V, Ives MJ. 2009. The effects of stream canopy management on macroinvertebrate communities and juvenile salmonid production in a chalk stream. Fisheries Manage Ecol 16: 100-111.

Sear DA, Armitage PD, Dawson FH. 1999. Groundwater dominated rivers. Hydrol Process 13: 255-276.

Snook D, Whitehead PG. 2004. Water quality and ecology of the River Lee: mass balance and a review of temporal and spatial data. Hydrol Earth Syst Sci 8: 630-650.

Stanford JA, Ward JV. 1993. An ecosystem perspective of alluvial rivers: connectivity and the hyporheic corridor. J North Am Benthol Soc 12: 48-60.

Stubbington R, Wood PJ, Boulton AJ. 2009. Low flow controls on benthic and hyporheic macroinvertebrate assemblages during supra-seasonal drought. Hydrol Process 23: 2252-2263.

Stubbington R, Boulton AJ, Little S, Wood PJ. 2015. Changes in invertebrate assemblage composition in benthic and hyporheic zones during a severe supraseasonal drought. J North Am Benthol Soc 34: 344-354.

Tod S, Schmid-Araya JM. 2009. Meiofauna versus macrofauna: Secondary production of invertebrates in a low and chalk stream. Limnol Oceanogr 54: 450-456.

Williams DD. 1989. Towards a biological and chemical definition of the hyporheic zone in two Canadian rivers. Freshwater Biol 22: 189-198.

Williams DD, Febria CM, Wong JCY. 2010. Ecotonal and other properties of the Hyporheic Zone. Fund Appl Limnol 176: 349-364.

Wood PJ, Boulton AJ, Little S, Stubbington R. 2010. Is the hyporheic zone a refugium for aquatic macroinvertebrates during severe low flow conditions? Fund Appl Limnol 176: 377-390. 
Appendix 1 Abundance (mean \pm SE) of most abundant taxa in the Rivers Frome and Piddle between seasons for the deep $\mathrm{HZ}(P=0.0025$ with Poisson correction, $\mathrm{M}-\mathrm{W}$ test).

\begin{tabular}{|c|c|c|c|c|c|c|}
\hline Taxa & $\begin{array}{l}\text { R. Frome } \\
\text { Summer }\end{array}$ & $\begin{array}{l}\text { R. Frome } \\
\text { Winter }\end{array}$ & $\begin{array}{l}\mathrm{M}-\mathrm{W} \\
P \text { value }\end{array}$ & $\begin{array}{l}\text { R. Piddle } \\
\text { Summer }\end{array}$ & $\begin{array}{l}\text { R. Piddle } \\
\text { Winter }\end{array}$ & $\begin{array}{l}\mathrm{M}-\mathrm{W} \\
P \text { value }\end{array}$ \\
\hline Fam. Chironomidae & $55.7 \pm 8.5$ & $33.6 \pm 10.4$ & 0.003 & $36.4 \pm 5.8$ & $40.4 \pm 17.2$ & 0.1 \\
\hline Nematoda & $10.5 \pm 1.6$ & $9.9 \pm 2.3$ & 0.86 & $6.3 \pm 1.03$ & $8.8 \pm 2.6$ & 0.4 \\
\hline Oligochaeta & $7.6 \pm 1.6$ & $4.1 \pm 2.3$ & 0.83 & $6.4 \pm 1.8$ & $5.28 \pm 1.6$ & 0.9 \\
\hline Epigean Cyclopoida & $0.3 \pm 0.25$ & $0.5 \pm 0.5$ & 0.9 & $1.4 \pm 0.8$ & $0.25 \pm 0.18$ & 0.57 \\
\hline Stygophylic Cyclopoida & 0 & $0.12 \pm 0.12$ & 0.31 & $2.09 \pm 1.8$ & $0.12 \pm 0.12$ & 0.3 \\
\hline Stygophilic Harpacticoida & $0.6 \pm 0.4$ & $0.25 \pm 0.17$ & 0.15 & $0.34 \pm 0.2$ & $0.4 \pm 0.3$ & 0.76 \\
\hline Epigean Harpacticoida & $1.5 \pm 0.5$ & $1 \pm 0.5$ & 0.6 & $2.9 \pm 0.8$ & $3.5 \pm 1.44$ & 0.98 \\
\hline Epigean Ostracoda & $0.8 \pm 0.35$ & $0.25 \pm 0.18$ & 0.3 & $4.3 \pm 2.1$ & $2.1 \pm 1.13$ & 0.44 \\
\hline Stygophylic Ostracoda & 0 & 0 & - & $0.12 \pm 0.08$ & $0.25 \pm 0.25$ & 0.97 \\
\hline Stygobitic Amphipoda & 0 & 0 & - & $0.3 \pm 0.7$ & 0 & 0.21 \\
\hline Fam. Glossosomatidae & $2.23 \pm 0.8$ & $9.6 \pm 1.9$ & $<\mathbf{0 . 0 0 1}$ & $2.8 \pm 0.7$ & $1.8 \pm 0.8$ & 0.28 \\
\hline Gammarus pulex & $4.6 \pm 1.24$ & $1.8 \pm 0.64$ & 0.33 & $7 \pm 2.15$ & $2.5 \pm 0.9$ & 0.06 \\
\hline Fam. Elmidae & $4.09 \pm 0.8$ & $4.03 \pm 1.1$ & 0.9 & $2.8 \pm 0.7$ & $1.8 \pm 0.8$ & 0.41 \\
\hline Fam. Philopotamidae & $0.5 \pm 0.28$ & $0.75 \pm 0.6$ & 0.9 & $0.75 \pm 0.3$ & $0.37 \pm 0.4$ & 0.28 \\
\hline Hydropsyche sp. & 0 & 0 & - & 0 & 0 & - \\
\hline Ephemeroptera & $0.5 \pm 0.2$ & $1.8 \pm 1.03$ & 0.4 & $0.46 \pm 0.2$ & $0.5 \pm 0.3$ & 0.81 \\
\hline Plecoptera & $0.06 \pm 0.06$ & 0 & - & 0 & $0.18 \pm 0.18$ & 0.15 \\
\hline Hydrachnaellae & $1.4 \pm 0.4$ & $0.8 \pm 0.4$ & 0.35 & $1.4 \pm 0.4$ & $0.8 \pm 0.75$ & 0.025 \\
\hline Halacarida & 0 & 0 & - & 0 & 0 & - \\
\hline
\end{tabular}

Appendix 2 Abundance (mean \pm SE) of most abundant taxa in the Rivers Rib and Lee between seasons in the deep $\mathrm{HZ}(P=0.0025$ with Poisson correction, $\mathrm{M}-\mathrm{W}$ test).

\begin{tabular}{|c|c|c|c|c|c|c|}
\hline Taxa & $\begin{array}{l}\text { R. Rib } \\
\text { Summer }\end{array}$ & $\begin{array}{l}\text { R. Rib } \\
\text { Winter }\end{array}$ & $\begin{array}{l}\mathrm{M}-\mathrm{W} \\
P \text { value }\end{array}$ & $\begin{array}{l}\text { R. Lee } \\
\text { Summer }\end{array}$ & $\begin{array}{l}\text { R. Lee } \\
\text { Winter }\end{array}$ & $\begin{array}{l}\mathrm{M}-\mathrm{W} \\
P \text { value }\end{array}$ \\
\hline Fam. Chironomidae & $44.2 \pm 8.3$ & $12 \pm 2.2$ & 0.036 & $10.1 \pm 2.5$ & $23.3 \pm 5.23$ & 0.002 \\
\hline Nematoda & $9.3 \pm 1.8$ & $22.4 \pm 8.3$ & 0.33 & $10.9 \pm 1.9$ & $11.3 \mathrm{v} 1.8$ & 0.3 \\
\hline Oligochaeta & $4.7 \pm 1.13$ & $14 \pm 3.6$ & 0.07 & $4.5 \pm 1$ & $9.3 \pm 2.3$ & 0.012 \\
\hline Epigean Cyclopoida & $3.5 \pm 1.15$ & $5.2 \pm 2.16$ & 0.23 & $3.6 \pm 1.14$ & $6.6 \pm 2.4$ & 0.12 \\
\hline Stygophylic Cyclopoida & $3.8 \pm 2.7$ & $3.4 \pm 1.02$ & 0.14 & $0.3 \pm 0.17$ & $0.2 \pm 0.2$ & 0.32 \\
\hline Stygophilic Harpacticoida & $0.7 \pm 0.5$ & $15.4 \pm 13.46$ & 0.44 & $0.28 \pm 0.22$ & $0.5 \pm 0.4$ & 0.48 \\
\hline Epigean Harpacticoida & $13.9 \pm 4.5$ & $51.8 \pm 31.17$ & 0.15 & $3.4 \pm 2.6$ & $5.7 \pm 3.12$ & 0.82 \\
\hline Epigean Ostracoda & $3.18 \pm 0.66$ & $5.6 \pm 2.5$ & 0.25 & $3.05 \pm 0.8$ & $1.8 \pm 1.02$ & 0.38 \\
\hline Stygophylic Ostracoda & $1.7 \pm 0.5$ & $5.3 \pm 3.3$ & 0.41 & $0.6 \pm 0.35$ & $0.8 \pm 0.7$ & 0.8 \\
\hline Stygobitic Amphipoda & $0.9 \pm 0.3$ & $1.6 \pm 0.7$ & - & $0.5 \pm 0.3$ & $1 \pm 0.7$ & 0.38 \\
\hline Fam. Glossosomatidae & 0 & 0 & - & 0 & 0 & - \\
\hline Gammarus pulex & $1.1 \pm 0.6$ & $1.1 \pm 1$ & 0.9 & $7.1 \pm 2.4$ & $3.14 \pm 1.02$ & 0.4 \\
\hline Fam. Elmidae & 0 & 0 & - & 0 & 0 & - \\
\hline Fam. Philopotamidae & 0 & 0 & - & $0.07 \pm 0.07$ & $0.5 \pm 0.28$ & 0.07 \\
\hline Hydropsyche sp. & $0.46 \pm 0.28$ & $1.6 \pm 1.5$ & 0.97 & $0.6 \pm 0.3$ & $1.3 \pm 0.5$ & 0.11 \\
\hline Ephemeroptera & $1.7 \pm 0.37$ & $0.37 \pm 0.2$ & 0.007 & $0.8 \pm 0.3$ & $1 \pm 0.6$ & 0.7 \\
\hline Plecoptera & $0.28 \pm 0.16$ & 0 & 0.21 & 0 & 0 & - \\
\hline Hydrachnaellae & 0 & 0 & - & 0 & 0 & - \\
\hline Halacarida & $0.3 \pm 0.2$ & 0 & 0.21 & $0.14 \pm 0.1$ & $0.14 \pm 0.14$ & 0.98 \\
\hline
\end{tabular}

Cite this article as: Pacioglu O, Robertson A. 2017. The invertebrate community of the chalk stream hyporheic zone: spatio-temporal distribution patterns. Knowl. Manag. Aquat. Ecosyst., 418, 10. 